\title{
Issues and Strategies in Promoting Democracy and Good Governance: Nigerian and Malaysian Examples
}

\author{
Abdulkadir M.S (Corresponding author), Jayum A A \& Zaid A.B \\ Department of Government and Civilization Studies \\ Faculty of Human Ecology, Universiti Putra Malaysia \\ 43400 UPM Serdang, Selangor, Malaysia
}

Tel: 60-10-272-3472Ｅ-mail:ms.abdulkadir@yahoo.com

Received: July 19, 2011

Accepted: November 22, $2011 \quad$ Published: January 1, 2012

doi:10.5539/ass.v8n1p259

URL: http://dx.doi.org/10.5539/ass.v8n1p259

\begin{abstract}
This paper examines both the political structures and institutions of Nigeria and Malaysia with a view of highlighting areas of similarities and differences in their modus operandi. While Malaysia has witnessed a tremendous boost and radicalism after 20 years of Prime Minister Tun Dr. Mahathir Mohamad's rule, Nigeria since the restoration of democracy in 1999, after a long military rule, did not yield a proper institutionalization of democratic principles. There have been cries against anti- and undemocratic practices of the eleven years old civilian government in Nigeria. The two countries under review operate a Federal Constitution, promote the principles of rule of law, protect the rights and liberties of the citizens but differ in the system of government. Malaysia operates parliamentary system while Nigeria is built on a presidential system. What went wrong and how can democracy be promoted and consolidated? The paper explores answers to the above question. The conclusion of this article is drawn on the premise of providing plausible suggestions that will promote democracy and good governance in the two countries.
\end{abstract}

Keywords: Democracy, Political structure, Party system, Political institution

\section{Introduction}

Pluralist democratic theory posits that democracy needs to be supported by the people and by a wide range of associations and other organized collectivities capable of articulating the interest of their members, moulding and constraining the power of the state, Becman, ( 1993:3 ). The more the people are involved in decision -making process, with active participation, the better for democracy. Pericles definition of democracy in Athens:

"Our constitution is named a democracy, because it is in the hands not of the few but of the many. Societies with weak people's participation in the affairs of government are argued to run the risk of undemocratic governance. To former Prime Minister of Russia, Com. Mikhail B. Gorbachev, "we need democracy like air. If we do not realise this, and even if we realise it but do not take real steps in expanding and advancing it, and involving the people of the country in the process of restructuring, our policy will choke," ( June, 1986).

Even though, Malaysia and Nigeria operates constitutional governments, there are some areas of glaring differences in their modus operandi. Malaysia has recorded several successful transitions government from one civilian regime to another, since the country gained her political freedom from the British imperialists in 1957. Nigeria got her independent in 1960 and has witnessed several military authoritarianism resulted in a series of political transition programmes between 1989 and 1999. Against the expectation of the people and the civil societies, the restoration of democracy in 1999 did not in way result to the proper institutionalization of democracy as compare to Malaysia. There have been increasing cries against anti- and undemocratic practices of the eleven years old civilian rule in Nigeria. These considerations have led to the increasing concern of the people and their role in the struggle for, and consolidation of democracy. This is the main thrust of this article with comparative analysis between Nigeria and Malaysia. However, the concept of democracy needs to be understood within the context of this presentation. 


\section{Literature Review}

Literature review in this paper takes on the concepts of Democracy, Political Structure, and Party System. These concepts have been major focus of this presentation. These concepts are often applied in a variety of ways. For instance, Sartori (1965: 19) conceives of democracy as "the power of the people and the rule of the people". Appadorai, (1975: 137) describes it as "a system of government under which the people exercise the governing power either directly or through representatives periodically elected by themselves". To Marxist point of view, as presented in the work of Marx and Engels (1981), the communist Manifesto, democracy connotes "the dictatorship of the proletariat ".

The concept of democracy has different interpretations. However, liberal universalism has dominated contemporary discourse on democracy, particularly the idea that there has been a total exhaustion of viable systematic alternatives to western liberalism, especially after the collapse of socialism in the Soviet Union and Eastern Europe and that this has translated to an ideological end point for mankind in favour of western liberal democracy. A prominent example of this is the view championed by Fukuyama, who posits that the collapse of socialist experience in Eastern Europe constitutes not just:

The passing of a particular period in cold war history but the end history as such; that is the end of mankind's ideological evolution and the iniversalization of western liberal democracy as final form of human government.

Robert Dahl, (cited in Martinussen, 1996) identified three core conditions for democracy:

1. Meaningful and extensive competition among individuals and organised groups (especially political parties) for all effective positions of government power, at regular intervals and excluding the use of force;

2. a highly inclusive level of political participation in the selection of leaders and policies, at least through regular and fair elections, such that no major adult social group is excluded; and

3. a level of civil political liberties- freedom of expression, press, etc, sufficient enough to ensure the integrity of political competition and participation (Martinussen, 1996: 303).

From the fore going discussions, it is imperative to note that liberal democracy is a "historical product, ideally constituted as the political correlate of advanced capitalism and its salient features ". Economically, it is market centric, socially it presupposes the collapse of mechanical solidarity and equality, respect for private property, the rule of law and government by consent (Ake, 1994:4).

The liberal perspective of democracy provides a rather reductive definition and understanding of the concept. Democracy, in the less developed capitalist countries like Nigeria and Malaysia need to go beyond these abstract political rights and take concrete economic and social rights seriously. It is a dynamic concept which should be continually evolving. It is more of a process and values (Totemeyer, 1994:50). Democracy invests heavily in the upliftment of the ordinary people so that they can participate effectively in governance and be more competitive in promoting their material interests (Ake, 1994:3). Sir Ahmadu Bello, the premier of Northern Region, and the Sardauna of Sokoto, is therefore, correct to say that " government has no business to be government if it is not build on an accepted constitution which will guarantee rule of law, protection of rights of citizens and promote greater happiness of the greater number of the people ".

\section{Political structure}

Political structure is a term used refers to institutions or groups and their relations to each other, their patterns of interaction within political systems and to political regulations, laws and the norms present in political systems in such a way that they constitute the political landscape of the political entity. Political structure of nations explains the type of government, constitution as well as pattern of democratic governance. Nigeria and Malaysia shares some level of similarities in this context. For instance, the Federal Constitution of Malaysia is the supreme law of Malaysia. The 1957 Constitution of the Federation of Malaya is the basis of this document. It establishes Malaysia as a constitutional monarchy having the Yang di-Pertuan Agong as the Head of State whose roles are largely ceremonial. It provides for the establishment and the organization of three main branches of the government: the bicameral legislative branch called the Parliament, which consists of the House of Representatives and the Senate; the executive branch led by the Prime Minister and consists of Cabinet Ministers; and the judicial branch headed by the Federal Court.

Executive power is vested in the cabinet led by the prime minister; the Malaysian constitution stipulates that the prime minister must be a member of the lower house of parliament who, in the opinion of the Yang di-Pertuan Agong, commands a majority in parliament. The cabinet is chosen from among members of both houses of parliament and is responsible to that body. 
The bicameral parliament consists of the Senate (Dewan Negara) and the House of Representatives (Dewan Rakyat). All 70 Senate members sit for 3-year terms, which are normally extended for an additional 3 years; 26 are elected by the 13 state assemblies, and 44 are appointed by the king following the prime minister's recommendation. Representatives of the House are elected from single-member districts by universal adult suffrage. The 222 members of the House of Representatives are elected to parliamentary terms lasting up to 5 years. Legislative power is divided between federal and state legislatures.

The Malaysian legal system is based on English common law. The Federal Court reviews decisions referred from the Court of Appeal; it has original jurisdiction in constitutional matters and in disputes between states or between the federal government and a state. Peninsular Malaysia and the East Malaysian states of Sabah and Sarawak each have a high court.

The federal government has authority over external affairs, defense, internal security, justice (except civil law cases among Malays or other Muslims and other indigenous peoples, adjudicated under Islamic and traditional law), federal citizenship, finance, commerce, industry, communications, transportation, and other matters. Federal Republic of Nigeria operates a federal constitution as well. The opening chapter of the constitution stipulates that:

This Constitution is supreme and its provisions shall have binding force on the authorities and persons throughout the Federal Republic of Nigeria.

The Federal Republic of Nigeria shall not be governed, nor shall any persons or group of persons take control of the Government of Nigeria or any part thereof, except in accordance with the provisions of this Constitution.

If any other law is inconsistent with the provisions of this Constitution, this Constitution shall prevail, and that other law shall, to the extent of the inconsistency, be void.

Nigeria is one indivisible and indissoluble sovereign state to be known by the name of the Federal Republic of Nigeria.

Nigeria shall be a Federation consisting of States and a Federal Capital Territory, Abuja.

Nigeria is a federation of 36 states with 774 local governments' areas. The 36 states are;

Abia, Adamawa, Akwa Ibom, Anambra, Bauchi, Bayelsa, Benue, Borno, Cross River, Delta, Ebonyi, Edo, Ekiti, Enugu, Gombe, Imo, Jigawa, Kaduna, Kano, Katsina, Kebbi, Kogi, Kwara, Lagos, Nasarawa, Niger, Ogun, Ondo, Osun, Oyo, Plateau, Rivers, Sokoto, Taraba, Yobe and Zamfara.

The Federal constitution of Nigeria is the supreme law of Nigeria. The Politics of Nigeria take place in a framework of a federal presidential representative democratic republic, whereby the President of Nigeria (Umaru Musa Yar'Adua) is both head of state and head of government, and of a multi-party system. Executive power is exercised by the government. Legislative power is vested in both the government and the two chambers of the legislature, the House of Representatives and the Senate. Together the two chambers make up the law-making body in Nigeria called the National Assembly. The highest judiciary arm of government in Nigeria is the Supreme Court of Nigeria. Nigeria also practices Baron de Montesquieu's theory of the separation of powers. The National Assembly serves as a watchdog to the excesses of the executive arm of government.

The document also defines the rights and responsibilities of the federal government, the member states of the federation and the citizens and their relations to each other.

The politics of Malaysia takes place in the framework of a federal constitutional monarchy, in which the Yang di-Pertuan Agong is head of state and the Prime Minister of Malaysia is the head of government. Executive power is exercised by the federal government and the 13 state governments. Federal legislative power is vested in the federal parliament and the 13 state assemblies. The judiciary is independent of the executive and the legislature, though the executive maintains a certain level of influence in the appointment of judges to the courts.

\section{Party System}

The total number of political party in any given state makes up a party system. This is described as the conduct of government based on the number of political parties within the system. For instance, the Constitution of Malaysia is codified and the system of government is based on the Westminster system.

Malaysia has a multi-party system since the first direct election of the Federal Legislative Council of Malaya in 1955 on a first-past-the-post basis. The ruling party since then has always been the Alliance Party (Malay: Parti Perikatan) coalition and subsequently from 1973 onwards, its successor the Barisan Nasional (National Front) coalition. The Barisan Nasional coalition currently consists of the United Malays National Organisation 
(UMNO), Malaysian Chinese Association (MCA), Malaysian Indian Congress (MIC) and 11 other political parties.

Although Malaysian politics has been relatively stable, critics allege that "the government, ruling party, and administration....are intertwined with few countervailing forces."[1]Although Malaysia is a federal state, political scientists have suggested that its "federalism is highly centralised":

"Our federalism gives the federal government not only the most legislative and executive powers but also the most important sources of revenue. State governments are excluded from the revenues of income tax, export, import and excise duties, and they are also largely restricted from borrowing internationally. They have to depend on revenue from forests, lands, mines, petroleum, the entertainment industry, and finally, transfer payments from the central government ", Chin, (2007).

Nigeria has a multi-party system, with two or three strong parties and a third party that is electorally successful. Political commentators have argued that political parties in Nigeria are culturally or ethnically oriented or based. That none has a national outlook. This assertion could be correct looking at the party formations and activities in Nigeria.

Below are number of political parties registered by various electoral bodies according to different republics in Nigeria.

\section{First Republic (1960-1966)}

- $\quad$ Action Group (AG)

- Borno Youth Movement (BYM)

- Democratic Party of Nigeria and Cameroon (DPNC)

- Dynamic Party (DP)

- Igala Union (IU)

- Igbira Tribal Union (ITU)

- Kano People's Party (KPP)

- $\quad$ Lagos State United Front (LSUF)

- Mabolaje Grand Alliance (MGA)

- Midwest Democratic Front (MDF)

- National Council of Nigeria and the Cameroons/National Council of Nigerian Citizens (NCNC)

- $\quad$ Niger Delta Congress (NDC)

- Nigerian National Democratic Party (NNDP)

- Northern Elements Progressive Union (NEPU)

- $\quad$ Northern People's Congress (NPC)

- Northern Progressive Front (NPF)

- $\quad$ Republican Party (RP)

- $\quad$ United Middle Belt Congress (UMBC)

- United National Independence Party (UNIP)

- Zamfara Commoners Party (ZCP)

\section{Second Republic (1979-1983)}

- Great Nigerian People's Party (GNPP)

- National Party of Nigeria (NPN)

- $\quad$ Nigeria Advance Party (NAP)

- $\quad$ Nigerian People's Party (NPP)

- People's Redemption Party (PRP)

- Unity Party of Nigeria (UPN)

\section{Abortive Third Republic}


- National Republican Convention (NRC)

- Social Democratic Party (SDP).

\section{Fourth Republic (1999-present)}

- Action Congress (AC)

- $\quad$ Advanced Congress of Democrats (ACD)

- African Democratic Congress (ADC)

- $\quad$ Alliance for Democracy (AD)

- $\quad$ All Nigeria Peoples Party (ANPP)

- $\quad$ All People's Party (APP)

- All Progressives Grand Alliance (APGA)

- Democratic Alternative (DA)

- Democratic People's Party (Nigeria) (DPP)

- National Democratic Party (NDP)

- $\quad$ New Democrats (ND)

- $\quad$ People's Democratic Party (PDP)

- People's Redemption Party (PRP)

- $\quad$ People's Salvation Party (PSP)

- United Nigeria People's Party (UNPP)

- $\quad$ Fresh Democratic Party (FDP)

- Communist Party of Nigeria (CPN)

- $\quad$ Progressive Peoples Alliance (PPA)

- People Progressive Party (PPP)

- Masses Movement of Nigeria (MMN)

- National Conscience Party (NCP)

- Democratic Socialist Movement (DSM)

- African Renaissance Party [ARP]

\section{The evolution of leaders}

In most societies leaders do emerged either as a result of ballot or bullet. The commonest pattern one sees in the third world countries is the latter. Essentially, good governance has to do with good leadership. Leadership that is participatory, service delivery, people oriented, people based and people centered. While Malaysia has gone through Five Prime Ministers since independent in 1957, Nigeria has experienced fifteen different national leaders since 1960 .

Frequent change of government has undermined political stability, economic development and has also dented Nigeria and Nigerian's image internationally. It is quite unfortunate that out of the fifty years of Nigeria political history, the military have had too much stay in power (twenty eight years) while the civilians have had too little. This scenario is a contradiction of Democratic principles.

The table below summaries total numbers of leaders the two countries (Nigeria and Malaysia) has produced since independent to date.

$<$ Insert Table 1 and Table 2 here $>$

\section{Promoting and consolidating democracy}

Promoting or consolidating democracy takes more than commitment to the principle of democracy, for democracy to be consolidated the ruling class, civil society groups and the mass of the people must all accept that the political system they are operating is worth defending. Democratic consolidation involves the promotion and strengthening of democratic values to make them impregnable to anti-democratic forces. This cannot simply be a question of establishing certain procedures but also the bringing about of critical pre- conditions like free 
and fair elections, political empowerment of the weaker sections of the society and building viable political institutions.

Beyond normative and behavioral changes expected from the ruling class and even the followership, in consolidating democracy there are three generic tasks that must be carried out:

- Service delivery or regime performance;

- Deepening democracy; and

- Political institutionasation.

Deepening democracy entails making democracy more liberal, representative, accountable, transparent and accessible. There is a strong relation between the depth of democracy and the legitimacy of the government in power. The more shallow, exclusive, unaccountable and abusive of individual and group rights are of the elected government, the less its legitimacy.

Political institutionasation is the movement towards a predictable pattern of political behavior. Intervention in the public realm aimed at strengthening institutions and institutional relationships is of particular importance for the proper functioning of a democratic government. This would at same time contribute to democratization outside the realm of the formal political system. The institutions of democracy are the basic structures upon which democracy strives. These must not be compromised. Although most of these institutions are not fully developed in Nigeria, it is the responsibility of the government to make them available and functional.

It is imperative to also note that democracy does not survive simply because of these institutions. Democracy endures because it responds to certain local values and ethics that enable its operators to accommodate local traditions. These norms are informed by the values of civil society. The long stay of the military in Nigerian politics has eroded civic political culture. The civil society must ensure that these values are imbibed and encouraged its internalization. Until that is achieved, democracy may not endure.

There is the need to also understand that democracy is not an event or occasion. It is a process. Therefore, serous shortcomings should not be wished away simply on the ground that the status quo is the only realistic thing possible to at present (Olukoshi, 1999). Furthermore, societies should only fashion out their democratic systems devoid of the western model. Understanding of Euro-centric nature of such belief, Ake (1999), noted that the practice of liberal democracy in much of the industrialized world is so "impoverished ", as such it is of limited value in the current African culture.

Service delivery or regime performance is the best parameter to assess the success or otherwise of any administration, military or civilian. It is equally important to understand that, people do not eat democracy, the state must provide or facilitate what people will eat (Abdu, 2000). This may mean jettisoning the market-centric Structural Adjustment Programme built and attached to the world capitalist system is replaced with an appropriate reform package that balances economic rationality with the welfare needs of the people (Olukoshi, 1999). Any economic programme that is not rooted on the people will be dangerous for democratic aspiration (Abdu, 2000).

To achieve democratic aspiration, self- reliance needs to be developed among the masses; participation in decision-making process must be encouraged and stimulated to create awareness of social reality. Empowerment is not only an issue of social education. It also involves organizing the masses and strengthening the organizations that represent them. It also implies removal of all economic, political and cultural barriers which prevented the masses from living fuller and more satisfactory lives (Martnussen, 1996:306). Therefore, civil society groups and government should address these issues by providing services to the rural areas and attention must be paid to the poorer sections of the society and recognize the masses as citizens with equal rights and obligations (Martinussen, 1996:307). For the civil society groups to perform these responsibilities they need some level of readjustment and strengthening.

The idea of servant leadership represents the highest refinement and the best requirement of any democratic government. Servant leadership under democratic system should be seen with the following qualities:

- Ability to initiate and pursues practical enduring and sustainable developmental programmes that could translate into higher living standard of the people.

- Given that the pen is mightier than the sword and even mightier with the sword; nations must be led by individuals who know the difference between right and wrong, the use and abuse of power and human rights. Leaders whose actions speaks louder than voice; after all, "the tiger does not shout its turpitude, rather it acts it "(Soyinka, in Okoli, 2003). 
- Commitment to public good, readiness to do things that will transform the lives of the people. Any committed leader should see leadership as a task, a task for the common good and fulfillment of people's needs and aspirations.

- Trust: This connotes the quality of being reliable, responsible, answerable and accountable to the people, since the people reserve the sovereign power. This way the leader establishes popular goodwill of the people which translates into a legitimized government.

- Sacrifice: This is the highest level of public spirit or civic devotion whereby the leader lets go his cherished personal needs in order to benefit his people (Okoli, 2007). This is the only way a nationalistic and patriotic leaders demonstrate their feelings while discharging national responsibilities.

It is important to note that the success of any democratic system is an outcome of a well coordinated cooperation between leadership and followership. The development of the society does not lie on the part of leadership or followership, but it is the complementing role of the two.

\section{Recommendations}

From the foregoing, it is quite obvious that good leadership is indispensable to the promotion and consolidation of democratic governance. The recommendations proffered here are not just for promoting democracy but ways of consolidating its principles. Promoting democracy does not provide for any specific strategy, it is along historical process. However, we wish to make the following recommendations.

1) What is generally required in any democratic settings is empowerment of the people. Empowerment here involves transforming the economic, social, psychology, political and legal circumstances of the current powerless. It involves the emergence of group identities, the development of autonomous and coherent popular organizations, and the defence of, and education about, the legal rights of the popular sector.

2) Establishment of reliable political institutions that would stimulate political awareness among the people of their rights and options for action open to them. This would encourage people's participation in governance as well as in decision-making process.

3) Independent electoral body. The electoral body or commission responsible to organize and conduct elections should be independent. Government should not directly or indirectly interfere with the activities of such bodies. Enough fund and materials should be made available to the body.

4) Elections should be conducted under an ideal democratic atmosphere in which the people are free to vote for any candidate of their choice without any form of threat, intimidation or rigging.

5) International observers should be invited to see and monitor the conduct of any national elections to give it international acceptance and support. Elections should be made open to all and free for people to see in order to win international recognition and backing.

6) Candidates and electorates should have free access to court or election tribunals. Before, during or after election, any aggrieved person or group of persons should have free access to court or tribunal to challenge malpractices. This will reduce tension and suspicion from the minds of the electorates as well as candidates.

\section{Conclusion}

This article focused on comparative analysis of both the political structure and institution of Nigeria and Malaysia with a view of identifying similarities and differences in their operations. The historical evolution of the two countries is examined within the context of leadership the two countries have produced since independent.

Issues and strategies in promoting and consolidating democratic principles are critically examined, having operationally defined the concept of democracy.

Some plausible recommendations have been proffered on how to consolidate and promote democracy. Finally, the conclusion is a brief recap of the content of the entire article.

\section{References}

Abdu, H. (2000). Democratic Culture and Civil Society. N.J Humanities Journals, Global Civil Society, 2004/5, Journal of Civil Society, p. xii

Ake, C. (1994, 1999). Democratization of Disempowerment in Africa. Center for Advanced Social Sciences (CASS) Occasional Monograph No.1, Port Harcourt, Nigeria.

Appadorai, A. (1975). Substance of Politics. Bombay: Oxford University Press. 
Bagu, C. (1996). Democratization Process in Africa and the role of Trade Unions. Journal of Democracy, Vol. 9 , No. 1, 140-53.

Bayart, J. (1988). Civil Society in Africa, In Patrick Chabal (ed) Political Domination in Africa. Cambridge University Press, Cambridge.

Beckman, B. (1993). Whose Democracy? Bourgeois versus Popular Democracy. Paper for Workshop on Expanding Nigerian Democratic Space, Lagos, Nigeria.

BOARDS OF PARASTATALS. Office of the Head of Service of the Federation. [Online] Available: http://hosf.gov.ng/civil_service/structure_2 (Dec. 21, 2009)

Bratton, M. (2001). Beyond the State: Civil Society and Associational Life in Africa. World Politics, Vol. XLI, No. iv, p.2

Conclusion. In John Funston (Ed.), Government and Politics in Southeast Asia, p. 413. Singapore: Institute of Southeast Asian Studies, Yap, Mun Ching (Dec 21, 2006), p. 415.

Eke, P. (2002). The Constitution of Civil Society in African History and Politics. In B. Canon et.al. eds. Democratic Transition in Africa. Ibadan: CREDU, (2000: 121)

Fukuyama, F. (1989). The end of History. National Interest, Summer, Washington.

Gorbachev, M. (1986). Cited in Donald Morrison 1988. A Time Book, An Intimate Bibliography.

Government Ministries in Nigeria. Commonwealth of Nations. [Online] Available: http://www.commonwealth-of-nations.org/Nigeria/Government/Government_Ministries (Dec. 21, 2009)

Ihonvebere, J. (1994). Governance, Economics, and Interdependence: Constraints and Possibilities in Sub-Saharan Africa. Mimeo, University of Texas.

ILBS. (2007). Federal Constitution of Malaysia. Kuala Lumpur: International Law Book Services.

Jeong, C. (2007). Fundamental of Development Administration. Selangor: Scholar Press.

Martinussen, T. (1996). Basic Conditions for Credible Democracy. Paper Presented at Center for Middle Eastern Studies, University of Gortenborg, Sweden.

Okoli, A. (2007). Democracy and Stewardship in Nigeria: Understanding the Notion of Servant Leadership. National Conference, CASSS, Kadpoly, Nigeria.

Olukoshi, A. (1999). State Conflict and Democracy in Africa: The complex Process of Renewal. In Richard Joseph ed. State, Conflict and Democracy in Africa. Lynne Riener, London.

Permanent Secretaries. Office of the Head of Service of the Federation. [Online] Available: http://hosf.gov.ng/civil_service/disposition_list_5 (Dec. 20, 2009)

Saba, A. (2007). Citizenship Education: A Guide to Democracy and Good Governance in Nigeria, New Edition. Alausa Graphics Press, Lagos Street, Kaduna, Nigeria.

Sartori, H. (1965). The Origin of Democracy: When Democracy Makes Sense. Cambridge: Cambridge University Press, 1989, p. 88.

Totemeyer, M. (1994). The Politics of Labour Adjustment: The Experience of the Nigerian Labour Congress. CODESRIA, Dakar.

USAID Nigeria mission: Nigeria administrative divisions. October 2004.

Wong, C. (2007-07-25). Weakened federalism in the new federation. The Sun. From Wikipedia, the free encyclopedia. 
Table 1. Summary of total number of National Leaders in Nigeria (1960- Current)

\begin{tabular}{|l|l|l|l|}
\hline S/N & NAMES & DURATIONS & NUMBER OF YEARS \\
\hline 1 & $\begin{array}{l}* * \text { Sir Abubakar Tafawa } \\
\text { Balewa }\end{array}$ & $1^{\text {st }}$ Oct.1960-Jan.15 ${ }^{\text {th }} 1966$ & 6 Years \\
\hline 2 & $*$ Johnson Aguiyi-Ironsi & 16 Jan 1966 - 29 Jul 1966 & 7 Months \\
\hline 3 & $*$ Yakubu Gowon & 1 Aug 1966 - 29 Jul 1975 & 9 Years \\
\hline 4 & $\begin{array}{l}* \text { Murtala Ramat } \\
\text { Mohammed }\end{array}$ & 29 Jul 1975 - 13 Feb 1976 & 201 Days \\
\hline 5 & *Olusegun Obasanjo & 14 Feb 1976 - 1 Oct 1979 & 3 Years \\
\hline 6 & $\begin{array}{l}* * \text { President of the } \\
\text { Republic Shehu Shagari }\end{array}$ & 1 Oct 1979 - 31 Dec 1983 & 4 Years \\
\hline 7 & $*$ Muhammadu Buhari & 31 Dec 1983 - 27 Aug 1985 & 2 Years \\
\hline 8 & $*$ Ibrahim Babangida & 27 Aug 1985-27 Aug 1993 & 8 Years \\
\hline 9 & $* *$ Ernest Shonekan & 26 Aug 1993 - 17 Nov 1993 & 81 Days \\
\hline 10 & $*$ Sani Abacha & 17 Nov 1993 - 8 Jun 1998 & 5 Years \\
\hline 11 & $*$ Abdulsalam Abubakar & 9 Jun 1998 - 29 May 1999 & 1 Year \\
\hline 12 & $* *$ Olusegun Obasanjo & 29 May 1999 - 29 May 2003 & 4 Years \\
\hline 13 & $* *$ Olusegun Obasanjo & 29 May 2003-29 May 2007 & 4 Years \\
\hline 14 & $* *$ Umaru Musa Yar'Adua & 29 May 2007- May 05, 2010 & 3 Years \\
\hline 15 & $* *[$ Goodluck Jonathan & (acting for Yar'Adua) & 3 Months \\
\hline 16 & $* *$ Goodluck Jonathan & 6 May, 2010- current & \\
\hline
\end{tabular}

- Military Leaders

** Civilian Leaders

Table 2. Summary of total number of National Leaders in Malaysia (1957- Current)

\begin{tabular}{|c|c|c|c|}
\hline $\mathrm{S} / \mathrm{N}$ & NAMES & DURATIONS & NUMBER OF YEARS \\
\hline 1 & $\begin{array}{l}\text { Tunku Abdul Rahman Putra Al - Haj } \\
\text { Father of Independence } \\
\text { 1st Prime Minister }\end{array}$ & $1957-1971$ & 14 Years \\
\hline 2 & $\begin{array}{l}\text { Tun Abdul Razak b. Hussein } \\
\text { Father of Development } \\
\text { 2nd Prime Minister } \\
\end{array}$ & $1971-1976$ & 5 Years \\
\hline 3 & $\begin{array}{l}\text { Tun Hussein b. Onn } \\
\text { Father of Unity } \\
\text { 3rd Prime Minister }\end{array}$ & $1976-1981$ & 5 Years \\
\hline 4 & $\begin{array}{l}\text { Tun Dr. Mahathir Mohamad } \\
\text { Father of Modernisation } \\
\text { 4th Prime Minister }\end{array}$ & $1981-2003$ & 22 Years \\
\hline 5 & $\begin{array}{l}\text { Dato' Seri Abdullah Ahmad Badawi } \\
\text { 5th Prime Minister }\end{array}$ & $2003-2009$ & 6 Years \\
\hline 6 & $\begin{array}{l}\text { Dato' Sri Mohd Najib bin Tun Abdul Razak } \\
6^{\text {th }} \text { Prime Minister }\end{array}$ & 2009-Current & \\
\hline
\end{tabular}

